is almost the same thing, on the output of the recuiver revision amplifier or on the grid modulating device:

Mr. Smyth has made a series of visual observations and recorded them photographically to study the effects of interference on tesit signals and also on actual programmes. No marked divergence of opinion was expressed by any of the observers as to what did or did not represent interference-free reception. Measurements were also made to determine whether continuous wave interference was more noticeable by reason of its effect on synchronization rather than on modulation of the picture brightness. Several photographs are given which illustrate well the effects of change of frequency on interference.

The main conclusions which have been deduced from Mr. Smyth's observations and tests are as follow. Interference $40 \mathrm{db}$.(decibels) below the level of the picture modulation has no visible effect; at $30 \mathrm{db}$. below a slight effect is produced; while at $20 \mathrm{db}$. or less the entertainment of the picture is seriously reduced. The annoyance value of the interference is not affected by the brightness level at which the picture is reproduced provided the picture is reproduced with reasonable fidelity. A simple picture such as black lettering on a white background without any half-tones can be reproduced without appreciable loss of detail in the presence of considerable interference if the amplifier or light. source is over-modulated in both the black and white directions.

\section{TEAK PLANTATION YIELD TABLES}

$\mathrm{R}$ ECENT research work exemplifies the close col laboration maintained between the Central Research Institute at Dehra Dun, India, and the local research officers maintained in the various provinces of the country. It also furnishes evidence of a wider connexion. The first yield tables for plantation teak were made by Bourne in 1919-21 for the Nilumbur teak plantation situated some fortyfive miles up the Beypur River'from Calicut on the west coast of Madras. This famous plantation was started by the collector of the district, Conolly, in 1844, and was for long regarded as the pioneer in this work. But in Java the Dutch had commenced to plant teak successfully at an earlier date; for in 1932 Dr. Wolff von Wülfing compiled some yield tables for teak plantations in Java which include trees up to one hundred and ten years of age.

Whether teak grown in pure plantations can ever equal in quality of timber the article produced when grown in a mixed forest, which is commonly Nature's own method, is perhaps doubtful. Owing, however, to the much higher price the timber fetches in comparison with that of its associates, it has been planted more extensively than any other single species ; and the cult has spread to Africa where it is an exotic. Existing plantations in India and Burma are now estimated to cover an area of roughly three hundred square miles, and about ten square miles are being added annually.

Until recently Bourne's Nilumbur yield table had been the only standard of reference available for teak grown in even-aged plantations. As it was based on growth measurements obtained from a single plantation it had considerable limitations in its application elsewhere. The Java 1932 yield tables were based on a greater range of quality and age; they were translated by Prof. H. G. Champion into English units ${ }^{1}$. It has been found that the tables recently compiled by the sylviculturist at the Research Institute $^{2}$ compare favourably with those of Dr. Wolff von Wülfing for Java; height-growth trends and the intermediate quality class boundaries for both the Indian and Javan tables almost exactly coincide, thereby rendering it possible to make close comparisons between the data given in the two tables. The authors express their thanks to Dr. Wolff von Wülfing for his permission to reproduce his tables in English units.

1 For. Bulletin No. 87 (1934).

Ind. For. Rec., New Series, Sylviculture. Yield and Stand Tables for Teak Plantations in India and Burma, by V. M. Laurie and Bakehi Sant Ram. (Gov. of India Press, Delhi 1940.)

\section{FORTHCOMING EVENTS}

\section{SATURDAY, NOVEMBER}

SOCIETY OF CHEMTCAL INDUSTRY (Food Group) (Joint meeting with the South Wales Section) (in the Physics Lecture Room, University College, Cardiff), at 3.15 p.m.-Dr. Magnus Pyke : "The Chemical Determination of Vitamins".

\section{MONDAY, NOVEMBER 3}

ROYAL GEOGRAPHICAL SOCIGTY (at Kensington Gore, London, 8.W.7), at 3 p.m.- Sir Jolin Russell, F.R.S.: "Reconstruction and Development in Eastern Poland, 1930-39".

\section{TUESDAY, NOVHMBER}

IN8TTruTroN of CIvIL ENGINEERs (at Great George Street, London, S.W.1), at 2 p.m.-Prof. Charles Edward Inglis, F.R.S.: Presidential Address.

Royar College of Surgeons of Englann (at the Royal Society of Medicine, 1 Wimpole Street, London, W.1), at $2.30 \mathrm{p.m}$.Mr. L. R.
Braithwaite: "The Ileo-Gastric Syndrome" (Moynihan Lecture).

WEDNESDAY, NOVEMBER 5

ROYAL Socrety of ARTs (at John Adam Street, Adelphi, London, W.C.2), at 1.45 p.m.-Sir Edward Crowe: "Co-operation for Production".

THURSDAY, NOVEMBER 6

ROYaL COLLEge of SURGEONS OF ENGLAND (at the Royal Society of Medicine, 1 Wimpole Street, London, W.1), at 3.30 p.m.-Dr. W. E Gye, F.R.S.: "Cancer of the Breast" (Imperial Cancer Research Fund Lecture)

\section{APPOINTMENTS VACANT}

APPLICATIONS are invited for the following appointments on or before the dates mentioned:

acting Headship of The Department of Geography-The Registrar, University College, Hull (November 6).

Lecturer IN Pharmacology-The Secretary and Registrar, University, Bristol (November 8 ).

Gradoate Lecturfr in THE ENGINEering Department-The Gec retary Branch, Cheltenham (November 10).

INFORMATION OFFICER, who should be a graduate in applied science -The Manager, Wrought Light Alloys Development Association, 34, New Street, West Bromwich (November 15).

Organizing Secremary-The Secretary, Association of Assistant Mistresses in Secondary Schools, Stoney Cockbury, Winchcombe, Gloucester (endorsed 'Appointment') (November 25).

RESEaroh Assistant IN Veterinary Sciknor under the Alan, Duke of Northumberland Memorial Fund-The Hon. Secretary, King's College, Newcastle-upon-Tyne (November 29).

Sanion Geography Mistrass-The Headmistress, County School for Girls, Beckenham, Kent (endorsed 'Geography').

Edudation OFHOER-The Wardens, Educational Settlement, Pontypool, Mon.

RESEarch Assistant IN THE EConomics DhParTMENT-The Registrar, University College, Exeter.

Editorial and Publishing Offices
MACMILAN \& CO.. LTD.,
ST. MARTIN'S STREET, LONDON, W.C.2.
Telephone: Whitehall 883! Telegrams : Phusis Lesquare London

